psychological and mental health are considered. Creative health is understood as individual's capacity for creating ingenious ideas, constructions, various works under conditions of overcoming considerable difficulties and obstacles. It is emphasized that creative health is not always connected with physical health and can contradict successful creative acts, which reduce personality's psychological safety. The principally important point is that psychological health should be provided by, first of all, personality's mental peace. According to the conception of psychological safety, the following components of it have been distinguished: sensor-perceptive, emotional, intellectual, general personal, mental. Based on the analysis and typification of people's manifestations in critical life circumstances, the specific character of approaches to preventing and correcting essential negative informational influences on a number of population groups (adequatehypertrophying, adequate-adequate, adequate-minimising, inadequate-adequate, inadequate-minimising, inadequatehyperbolising) has been identified. The people belonging to the adequate-hypertrophying group do not change their behaviour in response to extreme conditions. In the adequate-adequate group, the participants intensify their activities and improve its results in critical situations. The people from the adequate-minimising group slow down their activities and reduce activity when influenced by negative information. Having received some stressful information, the people from the inadequate-adequate group start frenzied, though not considered enough activities. People from the inadequate-minimising category try taking actions first, but after that, they become inactive rather quickly. The people belonging inadequate-hyperbolising group usually take no actions at all. It has been concluded that the system of personality's psychological health should provide many-sided perception and recoding of signals by a personality - their understanding, assessment, incorporation in the experience-based analysis and interpretations, decision-making on the basis of sensor-perceptive "acceptance" of information in terms of adequate behaviour. There is the need for integrated solving of the problem of supporting creative health and psychological safety of a personality by joint efforts of psychologists, health professionals, and educators with efficient use of recreational facilities.

Keywords: psychological health, creative health, psychological safety of a personality, recreation, informational influence.

Подано до редакиіï 01.09.2016

UDC:159. 964

Tamara Yatsenko, Doctor of Psychology, professor, academician of the National Academy of Educational Sciences of Ukraine, Head of the Department of Depth Psychocorrection and Psychosocial Rehabilitation,

The Bohdan Khmelnytsky National University of Cherkasy, 81, Shevchenko Boulevard, Cherkasy, Ukraine

\title{
THE ISSUE OF COMPLEMENTARITY PRINCIPLE IN DEEP COGNITION OF THE PSYCHE
}

The paper presents the approach applied for deep cognition of the psyche in its integrity (the conscious/the unconscious). The functional differences between the spheres of consciousness and the unconscious in terms of their asymmetry have been discovered. The use of the complementarity principle borrowed from quantum physics has been substantiated. Particular attention is paid to the method of active psychosocial cognition (APSC), which is characterised by following "the phenomenon of the psyche" with orientation at reviving respondent's self-preservation instinct, which is the basic and unequalled motivator for personality changes. Introduction of the complementarity principle predetermines the unity of the issue of providing people with proper aid and the tasks of scientific cognition of the phenomenon of the psychic.

Keywords: archetype, deep cognition (correction), development, integrity of the psyche (the conscious/the unconscious), complementarity principle (inherence of the spheres of consciousness and the unconscious, principle based on the unconscious), APSC method, the conscious, the unconscious.

Improvement of psychologists' expertise is determined by the search for effective methods of psychocorrection; consideration of priority area of counselling service development, which affects the level of the teaching and education of the younger generation. The formation of psychologist's expertise involves his/her mastering of the procedure of deep cognition of the psyche in its personalised nature.
Psychodynamic approach in depth psychology marked a new reference point in practical psychology development assimilating the ideas of psychoanalysis, Gestalt psychology, phenomenological and humanistic approaches. Psychodynamic paradigm is embodied in the method of active psychosocial cognition (APSC), which is the basis for deep investigations.

The aim of the paper is to raise an issue of knowing the psyche as a whole, which will draw attention to the 
functional specificity of the sphere of the unconscious, which is contradictory to the functions of consciousness; the necessity of using metaphoric and symbolic means of cognition having a visual component; introduction of the "complementarity principle" that involves the use of proper means of investigating the psyche as a whole (consciousness/the unconscious).

The tasks of the paper: to find out scientific and methodological background for using visualised means providing mediation in mutual transitions of "the internal to the external", the unconscious into consciousness.

The key idea is to demonstrate that laws of the psyche are flexible and synthesised with the findings of quantum physics in terms of introducing two variations of complementarity principle into psychology: the principle of "inherence of spheres of consciousness and the unconscious" and the principle of investigation based on the unconscious.

The paper proposed for readers' consideration is intended to outline the new psychodynamic approach to knowing the psyche as the integrity of functionally contradictory (asymmetrical) spheres of consciousness and the unconscious. This approach is attaining significance as long as practical psychology is intended to provide assistance to people, especially in crises and stressful situations. This fact compensates for limitations of the theoretical idea about the psychic in terms of being focused on the sphere of consciousness. In depth psychology, the psychic is considered as a unity and contradictory correlation of the sphere of consciousness and the unconscious. In this regard, complementarity principle is of particular importance, as long as it has an influence on the procedure, instrumentarium and methodological support of the process of diagnostics and correction. Personalised efficiency of depth correction depends on specialist's proper understanding of the above-mentioned principle.

Complementarity principle was introduced by $\mathrm{N}$. Bohr, the founder of quantum physics, in order to overcome the gap in understanding the universal physical reality in Newtonian and quantum perception. In psychology, this principle was defined in the best way in the work of a well-known Georgian psychologist A. Sheroziya in his collected book "The Unconscious". In particular, he notes that, "the psychic is different from the physical, that is why it should be separated from physical laws, as long as science in general is composed of physics and psychology as well as all things are either psychic or transpsychic (physical)" $[3$, p. 751$]$. This statement confirms the necessity for specifying the complementarity principle in psychology. We share the view of A. Sheroziya that, "both psychology and quantum physics should employ complementarity principle as a method of reproducing coherent view of the psyche" [3, p. 751-788].

$\mathrm{N}$. Bohr considered complementarity as the most elementary principle of orientation at existence of the whole. Complementarity principle is in agreement with the fact that mechanical (figural) and quantum (ideal) objects should be described in various research (experimentative) situations with the use of different terms. We are convinced that the same is true for academic and depth psychology. At the same time, not only quantum and mechanical objects should have common ground that should be taken into account, but conscious-unconscious phenomena of the psyche are inwardly correlated. In other words, the complementarity principle is referred to realities that are different in functional contrariety and incompatibility and at the same time promising in terms of investigating their integrity. N. Bohr considered it to be a distinct possibility to apply the complementarity principle in psychology having regard to the existence of consciousness and preconsciousness. W. K. Heisenberg and W. Pauli shared his opinion. In particular, W. Pauli placed greater focus on the necessity to overcome the gap between quantitative and qualitative parameters of phenomena. He stated, "The only acceptable point of view for us ... is to admit two sides of the reality quantitative and qualitative, physical and mental - as those that are compatible with each other" [2]. As for N. Bohr, he thought, "Even if we have to distinguish between objective and subjective reality, the distinguishing line may depend on the way we look at things" [2].

Considering the contradictory character of functionally asymmetric phenomena of the psyche that represent collectively the integrity of the phenomenon, we focused our attention on specifying the complementarity principle in psychology. Basing on the fact that the spheres of consciousness and the unconscious are characterized by both autonomy and interrelatedness, their dissociation leads to personality problems in a person, which can be solved in the process of diagnostics and correction with a professionally established dialogue.

From the perspective of psychodynamic theory, the complementarity principle can be implemented in psychology by means of applying two principles oriented at the specifics of subjective reality of the psychic - inherence principle and the principle based on the unconscious. The first one draws researcher's attention to the fact that two spheres the psyche are not only interrelated, but are implicitly involved in the actual process of another sphere's formation. If it is true, there is latent informational awareness, which is, without doubt, abridged in the sphere of consciousness, as long as Self does not have access to a certain part of information related to repression. This is not about the id as an inborn instance, but about the acquired form of the unconscious - preconsciousness - which is being formed throughout life (most actively in oedipal period). Disorders of direct correlations are determined by not only repression (with following-up resistance), but their synthesis predetermining the category of the nonexperiential. Archetypal semantics of the symbolic language of the unconscious is also unavailable for consciousness. It explains orientation of diagnostic and correctional process at expanding self-consciousness as a principal factor of psychocorrectional effect. Moreover, inherence principle indicates the existence of implicative activity of both spheres in behaviour. It follows herefrom that invisibility of the unconscious for consciousness, its unrepresentability is noth- 
ing else than one of its characteristics rather that demonstration that it does not exist.

The issue of involvement of consciousness (albeit latently given) in the formation of the unconscious (or rather preconsciousness) going on under the influence of repression mechanisms and resistance under the pressure of "censorship" of the super-ego remains understudied. Preconsciousness has information connection with the super-ego and energetic connection with the id in case the ego is unavailable. Introduction of the complementarity principle in deep cognition of the psychic makes it possible to specify more properly the subject of psychology in general and ways of knowing it.

Let us try to correlate inherence principle and principle based on the unconscious with the categories of isomorphism and homomorphism. We have proven that the substructure of the psyche (consciousness/the unconscious) are functionally interrelated under the principle of isomorphism (certain equality) and homomorphism (one latent determinant can determine various forms of behaviour) at the same time. Homomorphic interrelations of the unconscious with consciousness are its distinctive feature [1]. Let us explain it using the following example: any kind of isomorphism makes it possible to project the data displayed on the map on the area, however, not every object located in the area is displayed on the map.

Homomorphism can functionally easy receive the parameters of isomorphism, but not vice versa, isomorphism cannot change into homomorphism. The unconscious can make itself known in a symbolically visualised way by means of self-representatives, which are realised partially (a person knows "what he/she has depicted"), but not vice versa, i.e. depth determinacy of a self-representative remains unknown. In other words, we are not able to force something intentionally from consciousness into the unconscious using direct (volitional) methods or enquire about the motives that determined certain result in the same way, as well as we cannot retrieve it from there by our own volition. Self-representation involves spontaneity and involuntariness of responder's activity. Thus, unconscious determinacy of individual's psyche can be experienced by means of metaphoricity and mediatedness of means of perception. Causality of the unconscious is manifested homomorphically in the variety of behaviour forms (one determinant $\rightarrow$ a variety of behavioural means). It follows therefrom that homomorphic reality (the unconscious) is characterised by surrogated and synthesised character of factors, their matrix organization, which affects one's consciousness latently. It makes psychic reality significantly different from physical reality guided by the complementarity principle. The irony of it is that when we investigate the psyche as a whole (using embodied representatives of a person), we take into account physical law (for instance, "a tree cannot run"), which facilitates the knowing of implicit characteristics of the psychic in the unity of the ideal and the material. Cognition is facilitated by the process of emotive revitalisation (filling) of representatives in dialogical cooperation with an individual.
As noted before, psychology is closest to quantum physics as long as its accomplishments are not related to everyday language or temporospatial factors. In the context of knowing the psyche as a whole, the important fact is that when interpreting the above-mentioned "extraordinary" phenomena, a researcher should use understandable language that is familiar to the respondent (or rather follow him/her). In this case, theoretical and methodological generalisations concerning explanations of matter points of his/her problem are not taken into account. The irony of it is that the sphere of the unconscious can be only understood on the basis of the language and the laws of consciousness' functioning. Moreover, such kind of dynamics is not a straight bridge between psychodynamic theory and independent reality of the unconscious. Deep cognition, on the one hand, is based on inherency of the sphere of consciousness from the unconscious, and on the other hand, on functional difference, independence (autonomy), and therefore impossibility of direct cognition of the sphere of the unconscious, which is related to consciousness homomorphically. The issue of consciousness' involvement into "the micro world of the unconscious" can be specified in a number of important ideas:

- involvement of words into the formation (as well as cognition) of preconsciousness by means of displacing socially unacceptable impulses of the id;

energetic orientation of unconscious processes according to their logical interrelations with consciousness in case of functional asymmetry;

- archetypical capability of the psyche to recode unconscious meanings represented in consciously visualised (subjectified) forms that can be decoded in verbal and dialogical interaction. The latter involves unconsciously determined symbolisation mechanisms that are engaged into codification of ideal meanings into materialised ones and the process of their decoding.

The whole system of APSC is aimed at maintaining its participants' optimum of emotional loads in order to provide emotional perceptiveness of consciousness, maintaining capability of the ego to process the information obtained. It has been predetermined by the laws of "positive disintegration of the psyche and its repeated integration at higher level of individual's mental development" formulated by us. With regard to the specific character of reality of the unconscious, we must find ways of its proper investigation using capability of the psychic to be actualized spontaneously in the situation "there and then". For this purpose, we have introduced the principle based on the unconscious.

The principle based on the unconscious [4] predetermines (and reflects) methodological bases explaining demonstrations of the unconscious (in the synthesis with the conscious) in individual's behavioural act. This principle reveals the way of methodological implementation of the complementarity principle in the specifics of depth cognition organization based on certain postulates listed below. Moreover, many years' experience in carrying out APSC gives reasons to state that it is the principle based on the unconscious that is liaison between metaposition de- 
termined by the complementarity principle and its genuine (detailed) implementation in the very process of knowing specific reality of the psychic characterised by personalism. Description of the principle based on the unconscious involves background for optimisation of deep cognition within the borders of "the horizon" oriented at interconnectedness of consciousness with the unconscious, which explains their informational equivalence.

Let us introduce conceptual issues of the principle based on the unconscious:

- inner determinacy of spontaneous activity of respondent's psyche expressed in the spontaneity of his/her behaviour;

- irreversibility and uniqueness of individual's spontaneous activity:

- interrelation of processes of the psyche that are reversible and irreversible in time;

- simultaneity (synchronism of interrelations) of time and space in the unconsciousness;

- violation of the psyche's adherence to reality principle under the influence of principle of complacency (catalysed by desires of the id);

dependence of the peculiarities of the process of archetypal visualisation of the psychic on internal, depth determinants as well as on individual's conscious decision to use certain forms and means of self-presentation;

- subordinacy of the unconscious along with the realised to common, universal laws of equilibrium and interrelatedness of functionally asymmetric realities;

- involvement of symbolisation mechanisms (condensation, removing, allusion, etc.) into recoding of the meanings of the unconscious into visualised self- representatives and their decoding;

- informational reversibility with reciprocal transformation of the semantics of the unconscious into the parameters of "the external" (dichotomy of the internal with the external);

- implicitness of semantic aspects of visualised presenters of an individual that determine individualised character of their interpretation methods (unpacking);

- correspondence of instrumental aspects of depth cognition to the inner implicative arrangement of the psyche reluctant to volitional (planned) simulation, designing and modelling;

- reciprocal opposition and at the same time synthesis, latent intergatedness of the observable and unobservable (the unconscious);

- interrelation of non-verbal aspect of the psyche with the verbal one - latent reformatting from "the nonlinguistic" into "the linguistic" by means of dialogical cooperation in the system "psychologist - respondent" $(\mathrm{P} \leftrightarrow \mathrm{R})$

- relativity of irrational manifestations of the unconscious outwards resulting from the possibilities for its transition into the category of the rational by means of revealing semantic parameters;
- the capability of "the unconscious" for selfintegration, self-organisation, "self-assembly", which is manifested in the inner arrangement of the psyche;

- dependence of the possibilities for objectification of the unconscious on synchronisation of diagnostic and correction process with the consistency of energetic behavioural initiative arising from within the psyche;

overcoming contradiction of the psyche between determined and accidental phenomenon by means of understanding latent factors determining accidents;

- synthesis of unbalanced (contradictory) forces that predetermine (catalyse) the transition from chaos to order, to relative balance inside the unconscious;

- instantaneousness (convolution) of the processes of transition from one system to another one - from the unconscious (invisible, non-conscious) to the obvious, observable, and yet requiring decipher of the inner meaning;

- simultaneous involvement of "implicative order" into the rules of irreversibility (towards consciousness) and reversibility (towards the unconscious);

- transformation of semantic parameters of the unconscious from ideal into the embodied, visualised ones conveying inner meanings (informational equivalent);

- involvement of archetypes into the recoding of the unconscious into visualised embodied self- representatives implying informational equivalents;

- integratedness of the processes of the unconscious with the protective system expressed in permanent tendency "to force" (regardless of nature of the values, whether they are conditional or core), which is provided by distortion of socially perceptive reality.

The principle based on the unconscious is determined by regulations that cover peculiarities of the functioning of the unconscious as well as establish conditions facilitating actualisation of integrity of the psychic into research platform. This principle directs cognitive process to the account of peculiarities of the unconscious in terms of its functional asymmetry with regard to the sphere of consciousness in case of their mutual impact. The community of intrinsic and delusive reality (at emotional and sensual level) is supposed to be peculiar to the psyche, which should be taken into account in the process of diagnostics and correction.

Thus, in view of the foregoing, psychocorrective work with a person should be intended to actualisation of his/her spontaneous activity catalysed by unimplemented impulses, trace effects and fixations. In the course of a conversation, the psychologist's questions should be aimed at inducing the impulse that stimulates latent motivation of the respondent's behaviour in an emotive way. In other words, the conversation should be established according to the inner implicative disposition of the psyche.

Therefore, the introduction of the inherence principle and the principle based on the unconscious facilitate implementation of the complementarity principle that organises cognition of functionally asymmetric realities in their integrity. APSC method is targeted at neither consciousness 
nor the unconscious in their separability, but at mutual interconnectedness that can be figuratively called "the horizon" (boundless line of their unity). This is what the complementarity principle (which is implemented in deep cognition through the inherence principle and the principle based on the unconscious) orients at.

Efficiency of implementing the principle of inherence of the spheres of consciousness and the unconscious makes it possible to provide people with professional aid in the process of diagnostics and correction. Functional inherence of the psyche's substructures demonstrates that consciousness does not exist without unconsciousness and vice versa, without consciousness the category of the unconscious would not exist! Let us recollect what Z. Freud said, "Consciousness is not the master in its own house". In the diagnostic and corrective process, we rely on the fact that the psyche knows everything and at the same time does not know what it knows exactly. The inherence principle emphasises the specific character of understanding subjective reality compared to physical reality. In the material world, Newton's laws are effective without any subjective modifications made, whereas consciousness is under pressure of the system of automated protections, which determine defects in understanding the truth of the psychic invisibly, but invariably. All these factors predetermine personalism of reality of the psychic, which is always personalised. It is certain that specifying the complementarity principle in psychology is essential for discovering new perspectives of proper understanding of the psychic in its integrity, which is the target of depth psychocorrection carried out in combination with processual diagnostics.

Contradiction in research approach of theoretical and depth psychology is levelled out by different vectors of their cognitive orientation: in the first case - it is mathematically substantiated statistics; in the second one - knowing logical interrelations identified with the help of phenomenological (behavioural) material reflecting spontaneous manifestations of individual's psyche. It is spontaneity where the origins of genuine integrity subject to being explicated into the realia observed lie in; the latter are "decoded" in the process of conversational interaction $(P \leftrightarrow R)$. The most important thing in deep cognition is identifying information equivalents reflecting semantic aspect of interrelation between consciousness and the unconscious. This issue is still understudied in psychology.

At the attempt of studying the sphere of the psyche independently (for instance, academic and projective approaches), the integrity and appropriateness of this study is disturbed, which contradicts the complementarity principle. Among other things, projective methods are focused on the unconscious, while academic psychology deals with consciousness. The approaches listed above ignore the complementarity principle, which stimulates the study of genuine reality of the psychic as a phenomenological integrity.

Certainly, the study of the psyche oriented only at consciousness can exist due to independence of this sphere (along with the unconscious). However, it should be noted that the results of such an academic approach do not pro- vide essential data about the psychic, do not reflect its deep determinacy. Only methods dealing with self-induced manifestations of the psyche's integrity provide information efficient for making an impact on a person in terms of psychocorrection, which harmonises the structure of the psyche. Unfortunately, all the testing methods and training techniques are based on single-aspect study of the psyche (either - or); they regulate individual's behaviour a priori raising barriers on the way to adequate understanding of the psychic, which is capable of self-induced expression at the three levels: cognitive, emotive and functionally behavioural. It is important to bear in mind that the research was carried out among future psychologists (students), which means that they are socially adapted people meeting the criteria of mental health.

Special attention is given to the synthesising function of the system of psychological or psychological defence covering both conscious and unconscious spheres. Many years' experience in implementing APSC confirms destructive influence of the defence on the psyche, which is determined by their automatedness and miseries of childhood that bear excessive emotive load. Considering integrative involvement of the defence into both spheres of the psyche, we emphasise principal condition of the methodology of deep cognition - spontaneity and involuntariness of respondent's behaviour. It is unintentional activity of the psychic that makes it possible to explicate internal factors reflecting misfortunes emotionally experienced in the past, which are fixed in trace effects (without sacrificing emotive and energetic capacity, which is especially typical for oedipal period of individual's life).

Appropriateness of cognition in such a psychodynamic format involves minimisation of social orientation of individual's behaviour, which may conceal real deep motives. For this reason, for the best possible cognitive interaction of the participants attending APSC group it is necessary to provide conditions for deep cognition. It is facilitated by the principles of teamwork similar to humanist approach (K. Rogers, A. Maslow and others). Organisation of APSC refocuses participant's activity: from focusing on other person's characteristics to oneself (i.e. one's own display of the psyche); from academic criteria of statements to understanding emotional state of each participant of the group (including oneself) "there and then"; from analysis of peculiarities of human psyche to self-reflection, selfanalysis, self-cognition; from criticism to objectification of causal factors of behaviour; from focusing attention on the past (or future) to awareness of what is happening "there and then"; from advice, recommendations to understanding depth semantic parameters; from awaiting assessment (compliments) to identifying and understanding the nature of latent motives of one's own behaviour; from proneness to avoiding emotionally demanding situations to the development of capability to understand and analyse reasons that caused them; from awaiting clear recommendations on resolving a certain situation to understanding inner infantile motives generated by fixations, remains of the past; from feeling miserable to actualising self-preservation and fore- 
casting situations determined by the tendencies to "forcing to repeat", "walking in vicious circles", etc. In the process of APSC, a person acquires the ability to be "involved into the situations" and at the same time see it from the outside, reorient oneself from narrow "tunnel" view to its decentration, expanding the opportunities to embrace causal multifaceted nature of phenomena determinated by the unconscious, understanding the essence of latent processes and their relatedness to consciousness. The tendency for selfaffirmation in APSC group is automatically changed to the ability to identify oneself with other participants in deep cognition of the psyche and discover possibilities for new personal becoming of oneself and other participants.

The complementarity principle refocuses researcher's attention on the inherence of each sphere of the psyche (consciousness/the unconscious), so that he/she cannot ignore their mutual involvement into a certain behavioural act of an individual. The latter predetermines the specific character of means of perception that take into account absence of direct access to the unconscious sphere. In this context, the understanding of archetypal essence of symbolic means of selfexpression, which conceal elaborately latent intentions of activity of the psychic, gains particular importance. It illustrates the need for using figurative visualised means of selfpresentation by the participants of APSC groups (pictures, sculpturing, building models out of stones, etc.). Selfrepresentatives act as mediators in deep cognition and may be made by one's own hand or chosen from the ones offered by a psychologist. It is important that perception of the psyche cannot be provided only with the help of externally objectified means of self-expression: a self-representative acquires necessary reliability and performance (that facilitates cognition) only in the process of its "revival" - emotive and automatic self-filling in conversational interaction in the system $\mathrm{P} \leftrightarrow \mathrm{R}$. Conversation between a psychologist a respondent determines emotively motivational impulse of automatism of behaviour only in case of precise diagnostics. The latter obliges future psychologists to carry out personal psychocorrection that neutralises distortions of social perceptive reality that are determined by the system of psychological defence. A question is the main tool used by a psychologist during a conversation! Its diagnostic and corrective consistency can influence the dynamics of deep cognition in accordance with implicative order of the psyche. Phenomenological process of APSC has clear priorities in orienting its

\section{ЛІТЕРАТУРА}

1. Андрущенко, В. П., Яценко, Т. С. Філософсько-психологічні проблеми методології пізнання психіки / В. П. Андрущенко, Т. С. Яценко // Психологія і суспільство : укр. теор.-методол. соціогуманіт. часопис. - 2012. - №. 3. - С. 3-77.

2. Кирьянов, Д. Дополнительность и проблемы современного диалога науки и богословия // http://www.bogoslov.ru/text/255941.html

3. Шерозия, А. Е. Диалектика, принцип дополнительности и проблема познания психологической participants at revealing personality problems with the aim of correction.

It follows from the above that depth cognition involves both respondent and psychologist' participation in it. The achieving of optimal practical effect implies research potential (as well as the new stage) of scientific cognition of depth of the psyche. It is referred to prospects for reproducing inward nature of the psychic in its integrity in the plane of observation. Optimality of the practical effect involves prospects for next exploratory stage of the processing of the obtained stenographic data (including audio/video records) with the aim of intrinsic scientific generalisation.

The paper presents, on the one hand, background for the development of APSC method associated with solving the problems of pedagogical communication, interaction of a teacher with a student; on the other hand, it presents recent results of the development of scientific and practical (methodological) principles of deep cognition of the psyche. Particular attention is paid to the formation of APSC method, which is characterised by observance of "the phenomenon of the psyche" with regard to the fact "the psyche knows everything", with orientation at generating respondent's selfpreservation instinct - principal and unequalled motivator of personal changes. Personality problems experienced by an individual defuse self-preservation instinct, which leads to psychological suppression of the psyche. Introduction of the complementarity principle (implemented in psychology through the inherence principle and the principle based on the unconscious) predetermines the unity of the problem of rendering help to a person and the tasks of scientific cognition of the phenomenon of the psychic. Psychology's academic aiming at high status caused unreasonable fragmentation of theory and practice. It is our belief that the process of deep cognition, the beginning of which is associated with the focus on phenomenological parameters ("following somebody", respondent's spontaneous activity), should be complete in terms of theoretical and methodological generalisations. Many years' experience in correctional work proves that high status of psychology is not predetermined by mathematical techniques, but by the researcher's ability for dialogue with the nature of the psyche, which provides opportunities for approaching its objective and at the same time delicately personalised parameters that have been formed under the guidance of greatness of universal laws of the psychic and the Universe!

целостности: к неклассически ориентированной стратегии научного эксперимента в психологии / А. Е. Шерозия // Бессознательное : в 4 т. / [под ред.: Ф. В. Бассина, А. С. Прангишвили, А. Е. Шерозия]. Тбилиси : Мецниереба, 1978. - Т. 3. - С. 751-788.

4. Яценко, Т.С., Глузман, А.В. Методология глубинно-коррекционной подготовки психолога / Т. С. Яценко. - Днепропетровск : Инновация, 2015. C. 34 . 


\section{REFERENCES}

1. Andrushchenko, V. P., \& Yatsenko, T. S. (2012). Filosofsko-psykholohichni problemy metodolohii piznannia psykhiky [Philosophic and psychological issues of the methodology of cognition of the psyche]. Psykholohiia $i$ suspilstvo: ukrainskyi teoretyko-metodolohichnyi sotsiohumanitarnyi chasopys - Psychology and society: Ukrainian theoretical and methodological sociohumanitarian chronicle, 3, 3-77 [in Ukrainian].

2. Kiryanov, D. (n.d.). Dopolnitelnost i problemy sovremennogo dialoga nauki i bogosloviya [Complementarity and issues of contemporary dialogue of science and theology]. Retrieved from: http://www.bogoslov.ru/text/255941.html [in Russian].

3. Sheroziya, A. Ye. (1978). Dialektika, printsip dopolnitelnosti i problema poznaniya psikhologicheskoy tselostnosti: $\mathrm{k}$ neklassicheski orientirovannoy strategii nauchnogo eksperimenta $\mathrm{v}$ psikhologii [Dialectics, complementarity principle and the problem of knowing psychological integrity: towards non-classically oriented strategy of scientific experiment in psychology]. Bessoznatelnoe - The unconscious, 3, 751-788. F. V. Bassin, A. S. Prangishvili, A. Ye. Sheroziya (Eds.). Tbilisi: Metsniereba [in Russian].

4. Yatsenko, T. S., \& Gluzman, A. V. (2015). Metodologiya glubinno-korrektsionnoy podgotovki psikhologa [Methodology of depth correctional preparation of a psychologist]. Dnepropetrovsk: Innovatsiya [in Russian].

\section{Тамара Семенівна Яценко, доктор психологічних наук, професор, академік НАПН України, завідувач кафедри глибинної психокорекції та психолого-соціальної реабілітації, Черкаський національний університет імені Богдана Хмельницького, бул. Шевченко, 81, м. Черкаси, Україна}

\section{ПРОБЛЕМА ПРИНЦИПУ ДОДАТКОВОСТІ В ГЛИБИННОМУ ПІЗНАННІ ПСИХІКИ}

У статті представлено глибинний підхід до пізнання психіки в їі цілісності (свідоме/несвідоме). Розкрито функціональні відмінності сфери свідомості і несвідомого в аспекті асиметричності. Несумісність двох сфер психіки породжує необхідність пошуку засобів цілісної самопрезентації суб'єкта в візуалізованих, опредмечених формах. Стверджується, що символ і архетип є взаємопов'язаними поняттями, причетними до візуалізації суперечливої сутності психіки суб'єкта. Факт непрезентованості несвідомого в свідомому «Я» суб'єкта зумовлюють необхідність запровадження опосередкованих засобів самовираження психіки, об’єктивно представлених у сфері спостереження. Обгрунтовується введення принципу додатковості, запозиченого з квантової фізики в психологію, який організаційно структурує методологію глибинного пізнання психічного і відкриває перспективи пізнання психіки в їі індивідуальній неповторності. Цей принцип реалізується на основі принципу невід'ємності сфер свідомості та несвідомого і принципу «з іншого». Грунтуючись на факті, що сферам свідомості та несвідомого характерна як автономія, так і взаємовіднесеність, стверджується, що порушення взаємозв'язків між ними призводить до виникнення особистісних проблем у суб'єкта, які можуть бути розв'язані в діагностично-корекційному процесі з професійно побудованим діалогом. Адекватність реалізації принципу невід'ємності сфер свідомості та несвідомого задає професійний формат діагностично-корекційної процедури надання допомоги людині. При спробах автономного пізнання сфер психіки (наприклад, академічний і проектний підходи) порушується цілісність, адекватність пізнання, що суперечить принципу додатковості. Описуються витоки формування методу АСПП (активного соціально-психологічного пізнання), пов'язані з вирішенням проблем педагогічного спілкування, взаємодії педагога з вихованцем, а також наводяться пізніше отримані результати розробки науково-практичних (методологічних) основ глибинного пізнання психіки. Особливу увагу приділено становленню методу АСПП, для якого характерно слідування «за феноменом психіки», орієнтуючись на пробудження у респондента інстинкту самозбереження - провідного (головного) і неперевершеного мотиватора особистісних змін. Випробовувані суб'єктом особистісні проблеми приглушують інстинкт самозбереження, що каталізує виникнення тенденції до психологічного імпотування психіки. Запровадження принципу додатковості зумовлює єдність проблеми надання оптимальної допомоги людині з завданнями наукового пізнання феномена психічного.

Ключові слова: архетип, глибинне пізнання (корекція), розвиток, цілісність психіки (свідоме/несвідоме), принцип додатковості (невід’ємність сфер свідомого і несвідомого, принцип «із іншого»), метод АСПП, свідоме, несвідоме.

Тамара Семеновна Яценко, доктор психологических наук, профессор, академик НАПН Украины, заведующая кафедрой глубинной психокоррекции и психолого-соичиальной реабилитации, Черкасский национальный университет имени Богдана Хмельницкого, бул. Шевченко, 81, г. Черкассы, Украина

ПРОБЛЕМА ПРИНЦИПА ДОПОЛНИТЕЛЬНОСТИ В ГЛУБИННОМ ПОЗНАНИИ ПСИХИКИ

В статье представлен глубинный подход к познанию психики в ее целостности (сознательное/бессознательное). Раскрыты функциональные отличия сферы сознания и бессознательного в их ассиметричности. Несовместимость двух сфер психики порождает необходимость поиска средств целостной самопрезентации субъекта в визуализиро- 
ванных, опредмеченных формах. Утверждается, что символ и архетип являются взаимосвязанными понятиями, причастными к визуализации противоречивой сущности психики субъекта. Факт непредставленности бессознательного в сознательном «Я» субъекта обусловливают необходимость введения опосредованных средств самовыражения психики, объективно представленных в сфере наблюдения. Обосновывается введение принципа дополнительности, позаимствованного из квантовой физики в психологию, который организационно структурирует методологию глубинного познания психического и открывает перспективы познания психики в ее индивидуальной неповторимости. Данный принцип реализуется на основе принципа неотъемлемости сфер сознания и бессознательного и принципа «из иного». Основываясь на факте, что сферам сознания и бессознательного характерна как автономия, так и взаимосоотнесенность, утверждается, что нарушение взаимосвязей между ними приводит к возникновению личностных проблем у субъекта, которые разрешимы в диагностикокоррекционном процессе с профессионально построенным диалогом. Адекватность реализации принципа неотъемлемости сфер сознания и бессознательного задает профессиональный формат диагностикокоррекционной процедуры оказания помощи человеку. При попытках автономного познания сфер психики (к примеру, академический и проективный подходы) нарушается целостность, адекватность познания, что противоречит принципу дополнительности. Описываются истоки формирования метода АСПП (активного социально-психологического познания), связанные с решением проблем педагогического общения, взаимодействия педагога с воспитанником, а также приводятся более поздние результаты разработки научно-практических (методологических) основ глубинного познания психики. Особое внимание уделено становлению метода АСПП, для которого характерно следование «за феноменом психики», ориентируясь на пробуждение у респондента инстинкта самосохранения - ведущего (главного) и непревзойденного мотиватора личностных изменений. Испытываемые субъектом личностные проблемы приглушают инстинкт самосохранения, что катализирует возникновение тенденции к психологическому импотированию психики. Введение принципа дополнительности предопределяет единство проблемы оказания оптимальной помощи человеку с задачами научного познания феномена психического.

Ключевые слова: архетип, глубинное познание (коррекция), развитие, целостность психики (сознательное/бессознательное), принцип дополнительности («неотъемлемость сфер сознательного и бессознательного», принцип «из иного»), метод АСПП, сознательное, бессознательное.

Подано до редакиії 01.09.2016

УДК: 159.9 .075

Анастасія Костянтинівна Базиленко, аспірант кафедри психології, Університет «Україна», вул. Львівська, 23, м. Київ, Украӥна

\section{ПСИХОЛОГІЧНИЙ ТРЕНІНГ СОЦІАЛЬНОЇ АКТИВНОСТІ СТУДЕНТІВ: ЗМІСТ ТА ЕФЕКТИВНІСТЬ ЗАСТОСУВАННЯ В ОСВІТНЬОМУ ПРОЦЕСІ ВНЗ}

У статті описано зміст психологічного тренінгу соиіальної активності студентів. Висвітлено особливості його застосування в освітньому процесі ВНЗ у вигляді спецкурсу, щуо складається з трьох модулів: «Сенс та иінності студентського життя», "Соціальна активність студента: особиста відповідальність», "Студентське самоврядування і соиіальна активність майбутніх фахівців». Наведено дані порівняльного аналізу динаміки рівнів соиіальної активності загалом і ї̈ структурних компонентів, зокрема в експериментальній та контрольних групах. Аналіз результатів упровадження авторської програми в освітній прочес ВНЗ засвідчує ї̈ ефективність щзодо підвищення рівня сочіальної активності студентів.

Ключові слова: соціальна активність, студентська молодь, компоненти соичіальної активності, розвиток соиіальної активності, освітній процес ВНЗ.

Актуальність проблеми розвитку соціальної активності студентської молоді зумовлена необхідністю забезпечення піi активної участі у процесі створення матеріальних і духовних благ суспільства; формування особистості конкурентоспроможного професіонала, здатного виявляти соціальні ініціативи, засвоїти та інтеріоризувати суспільні цінності й ідеали, ефективно виконувати соціальні функції та ролі у всіх сферах життєдіяльності.

У контексті розв'язання цієї проблеми нами була розроблена модель соціальної активності студентів, у структурі якої виокремлено мотиваційний, ціннісний, 